ARTICLE HISTORY: Received: September 05, 2021 Accepted: October 28, 2021 Published: November 04,2021

\title{
NON-DESTRUCTIVE CONTROL OF A HYDRAULIC HAMMER PISTON, DESIGNED FOR GEOLOGICAL
} EXPLORATION ACTIVITIES

\author{
Kamelia Kalchevska \\ Institute of metal science, \\ equipment and technologies with hydro and aerodynamics centre "Akad. A. Balevski, \\ Bulgarian Academy of Sciences \\ 67 Shipchenski prohod, 1574 Sofia, Bulgaria
}

\begin{abstract}
БЕЗРАЗРУШИТЕЛЕН КОНТРОЛ НА БУТАЛО ОТ ХИДРАВЛИЧЕН ЧУК, ПРЕДНАЗНАЧЕНА ЗА ГЕОЛОГО-ПРОУЧВАТЕЛНИ ДЕЙНОСТИ
\end{abstract}

Камелия Калчевска

Abstract. The piston part provided to us by the Bulgarian company to clarify the reason for its breakage.

Keywords: steels, non-destructive testing, macrostructure

1.Standards used in peer review:

1.BS EN 13018:2016 Non-destructive testing. Visual testing. General principles Released: 2016-02-29; 2.BS EN 13927:2003 Non-destructive testing. Visual testing. Equipment, 2003;

3. BS ISO 5579:2013 Non-destructive testing — Radiographic testing of metallic materials using film and X- or gamma rays - Basic rules;

4. ISO 3452-1:2013 Non-destructive testing — Penetrant testing — Part 1: General principles;

5.ISO 3452-2:2013(en) Non-destructive testing — Penetrant testing — Part 2: Testing of penetrant materials;

6.BS EN 10228-2:2016 Non-destructive testing of steel forgings. Penetrant testing;

7.ISO 23277:2015 Non-destructive testing of welds - Penetrant testing- Acceptance levels;

8.ISO 10675-1:2016 Non-destructive testing of welds - Acceptance levels for radiographic testing - Part 1: Steel, nickel, titanium and their alloys;

9.EN ISO 17637:2016 Non-destructive testing of welds - Visual testing of fusion-welded joints;

10. EN 1371-2:2015 Liquid penetrant testing - Part 2: Investment castings.

2.1. Test method:

1.2. Visual inspection according to standards [1], [2]. No defects in the base metal, as well as surface staining are observed.

2.2. Material - after the spectral analysis it was found that the sample is made of steel type 40Ch2N2MA.

Analog to DIN 1.6565 40NiCrMo 6.

Analog: Japanese brand JAPAN JIS № G 4103 steel grade SNCM8 of type.

The rolled product made of the above-mentioned material with $\phi 160 \mathrm{~mm}$ and in the range of $100 \div 400 \mathrm{~mm}$ is with subsequent heat treatment of the forging-hardening $850 \mathrm{oC}$ in oil and annealing at $610 \mathrm{o} \mathrm{C}$, which allows a part made with additional machining to be loaded to energy impact $5120 \mathrm{~J}$ according to the provided documentation. 


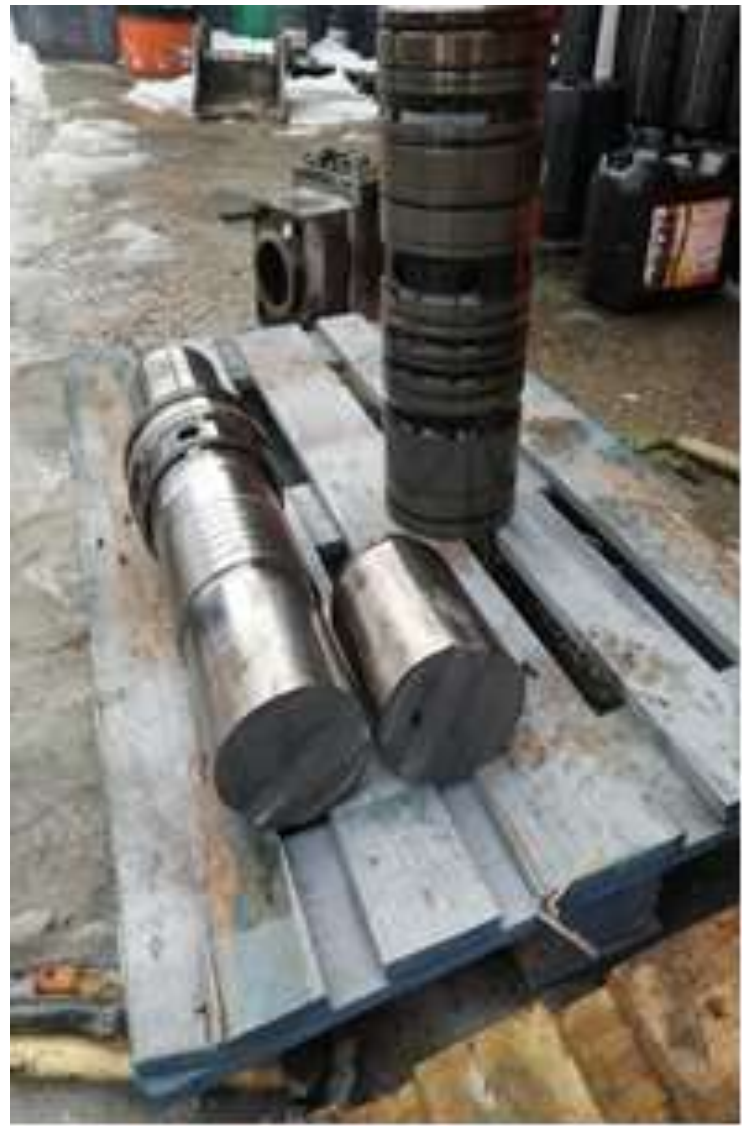

Figure 1 Broken piston- FUROKAWA

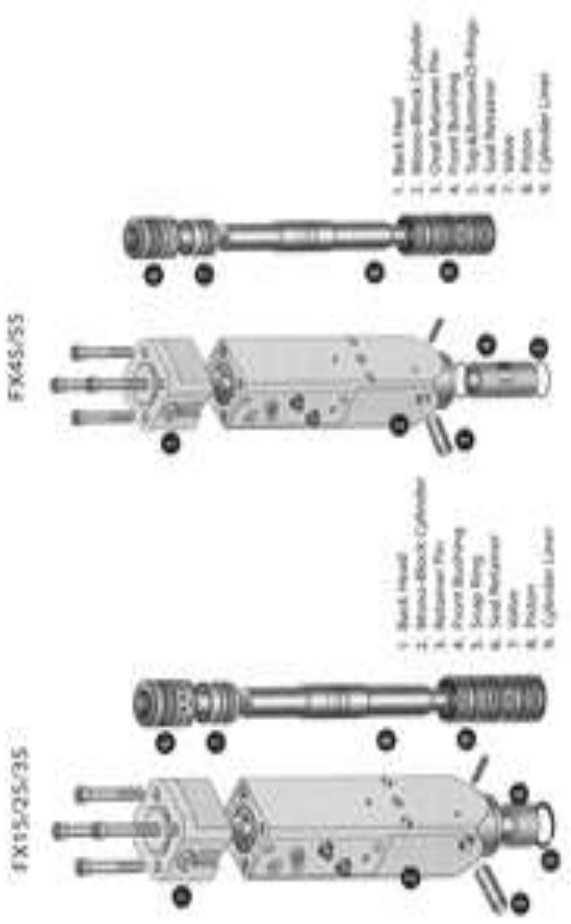

Figure 2 Drawing of the piston

by documentation, item 8

2.3 After the performed radiographic control according to the current standards BDS EN ISO [3] and [8], Figures 3 and 4 show the found inadmissible pores and voids $A>10 \%$. 


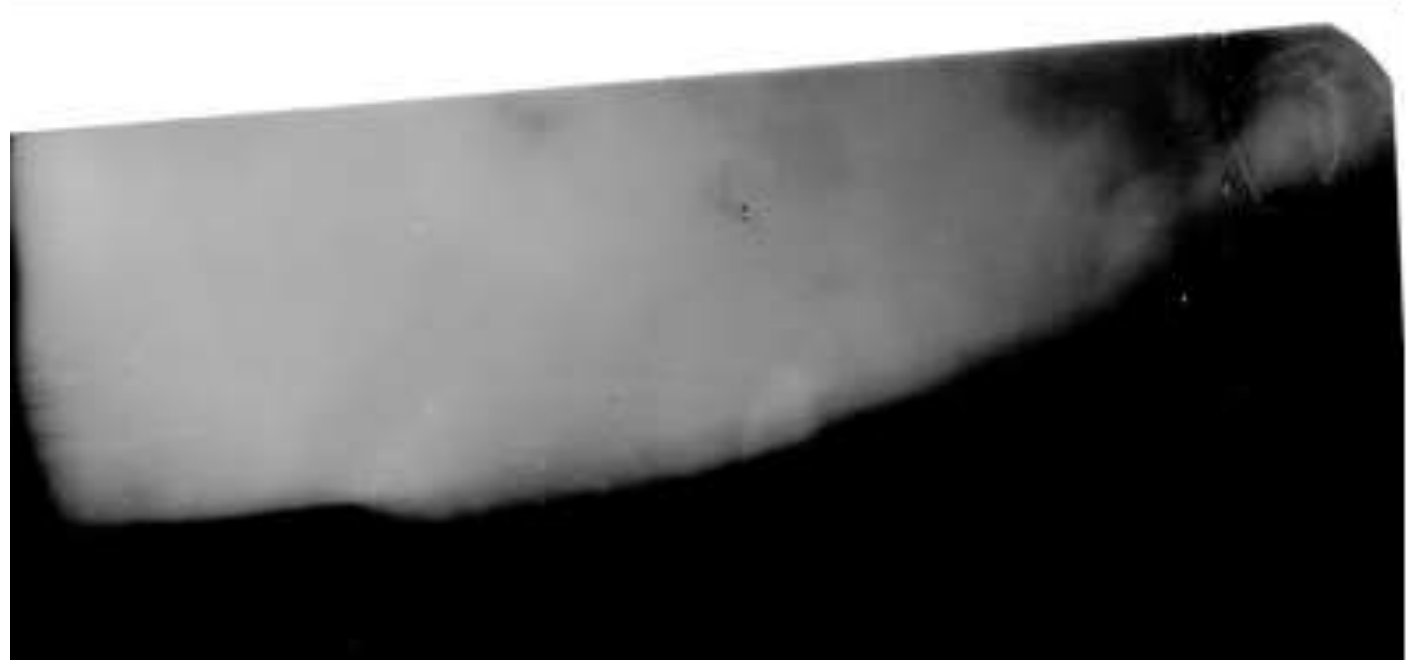

Fig. 4

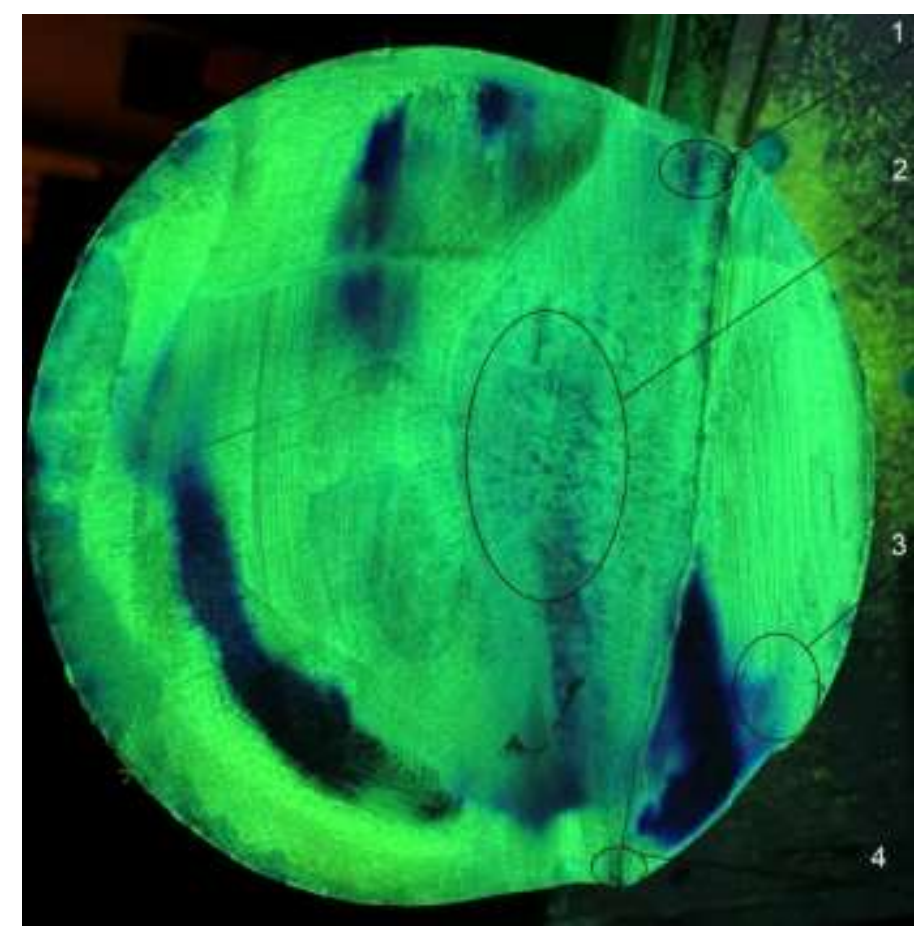

Fig.5 Analysis with penetrating liquids

1-cluster of pores in the area of the fracture and an initial crack with a length of about $35 \mathrm{~mm}$

2-cracks min 15 pieces with lengths between 1.5 and $12 \mathrm{~mm}$

3 -single pores with dimensions between 0.5 and $2 \mathrm{~mm}$

4-pores and a crack measuring about $9 \mathrm{~mm}$

3. Conclusion-The FUROKAWA FXJ 275 hydraulic hammer part was broken due to the large number of cracks inside the forging, as well as pores and cracks at two diametrically opposite ends, leading to the formation and development of a highway crack.

\section{Literature}

1.БДС EN 13018-03 Визуален контрол . Общи положения;

2.БДС EN 13927-03 Визуален контрол. Изисквания;

3. БДС EN ISO 5579:2013 Изпитване (контрол) без разрушаване. Радиографично изпитване на метални материали с използване на филм чрез рентгеново и гама льчение. Основни правила;

4.БДС EN ISO 3452-1:2013 Изпитване (контрол) без разрушаване. Изпитване с проникващи течности. Част 1: Общи принципи; 
5.БДС EN ISO3452-2:2013 Изпитване (контрол) без разрушаване. Изпитване с проникващи течности. Част 2: Изпитване на материали за изпитване с проникващи течности;

6.БДС ISO 10228-2:2016 Изпитване (контрол) без разрушаване на стоманени изковки. Част 2: Изпитване с проникващи течности;

7. БДС EN ISO 23277:2015 Изпитване с проникващи течности. Нива на приемане.

8.БДС EN ISO 10675-1:2017 Изпитване без разрушаване на заварени съединения. Нива на приемане при радиографично изпитване. Изпитване без разрушаване на заварени съединения;БДС EN ISO 17637:2016Визуално изпитване на заварени чрез стопяване съединения.

Kamelia Kalchevska Assoc.Prof. Ph.D, PT, RT,VT, Expert in X-ray flaw detection at the Institute of Metallurgy, Equipment and Technologies with the Center for Hydro- and Aerodynamics "Acad. Angel Balevski "

All equipment and experimental units used in this work was funded by the European Regional Development Fund within the OP "Science and Education for Smart Growth 2014 - 2020", project CoE "National center of mechatronics and clean technologies", № BG05M2OP001-1.001-0008-C08. 